\title{
IAMJ
}

INTERNATIONAL

AYURVEDIC

MEDICAL JOURNAL

\section{EFFECT OF GHONTAPHALADI VARTHI IN THE MANAGEMENT OF PERIANAL SINUS - A CASE REPORT}

\author{
Sreeparvathy A.G ${ }^{1}$, Sivakumar. C. $S^{2}$, Deepa. M. $S^{3}$ \\ ${ }^{1}$ PG Scholar, Dept of Salyatantra, Government Ayurveda College, Trivandrum, Trivandrum, India \\ ${ }^{2} \mathrm{MD}(\mathrm{Ay})$ - Guide, Professor, Dept of Salyatantra, Government Ayurveda College, Trivandrum, India \\ ${ }^{3} \mathrm{MS}(\mathrm{Ay}) \mathrm{PhD}$, Coguide, Associate Professor, Government Ayurveda College, Trivandrum, India
}

Corresponding Author: sreeparvathyag@gmail.com

https://doi.org/10.46607/iamj5809102021

(Published Online: October 2021)

Open Access

(C) International Ayurvedic Medical Journal, India 2021

Article Received: 27/09//2021 - Peer Reviewed: 07/10/2021 - Accepted for Publication: 08/10/2021

\section{Check for updates}

\begin{abstract}
Nadi Vrana is a term used to describe the sinus. Sinus is a blind track lined by granulation tissue from an epithelial surface.it can be treated mainly by Ksharasutra therapy and by other methods which include varti, Lepana etc. In Susrutha Samhitha Chikitsasthana first chapter Dwivarineeya chikitsa; it is mentioned that the Vrana Varthi ${ }^{1}$ can be used in Nadi Vrana where the wound is having minute opening, deep and going into the Mamsadhatu (muscles). In the present case study, a 44-year-old male patient visited the OPD with Grade 1 inter sphincteric sinus in the perianal region and the patient was selected for application of the Ghontaphaladi Varthi. Daily application of Ghontaphaladi Varthi has shown significant changes in the healing of the track and a decrease in the severity of the associated symptoms like pain and discharge.
\end{abstract}

Keywords: Nadi Vrana, Ghontaphaladi Varthi, Sinus

\section{INTRODUCTION}

Nadi Vrana is a term used to denote sinus. Sinus is a blind track that connects a cavity lined with granulation tissue, often an abscess cavity, with an epithelial surface. It produces a serous or purulent discharge and persists until the deep cavity closes. The symptoms include pain, discharge of pus or pus mixed with blood. Here the study is undertaken in the perianal sinus which are the precursors of fistula in 
ano. Being the track is lined by epithelium and due to the presence of fibrosis, the collapse of the track is prevented.so if it is left untreated it leads to deeper tissues forming fistula in ano. Even after the tremendous progress in modern surgery, this disease exists as a challenging case. Since the operative treatment has its own limits, it is the need of the time for a better treatment that is more convenient and costeffective for a sinus patient. In Ayurveda various acharyas have mentioned different treatment modalities for Nadi Vrana chikitsa. The treatment must aim at sodhana and ropana. The Ksharasutra application is a cost-effective treatment, but it is a painful procedure. Since in this case, as an alternative to the Ksharasutra chikitsa; Varthi prayoga is mentioned. In the Dwivraneeya adhyaya while mentioning the Dushta Vrana chikitsa, sodhana Varthi for the purification or elimination of doshas and ropana Varthi of healing property are mentioned. It is indicated in wounds with minute opening, and pus discharge. So Varthi prayoga is selected in this case. One among them is Ghontaphaladi Varthi which is mentioned in Susrutha Samhitha, visarpa nadi sthanaroga chikitsa as "hanthi achirena nadi.

\section{Preparation of Ghontaphaladi Varthi}

Ghontaphalatwak (Zizphus jujubae,) Panchalavana, laksha (Laccifer lacca), pugiphala (Areca catechu) alavan patra (Celestrus paniculatus) are taken in equal quantity and mixed with enough snuhi (Euphorbia neerifolia) ksheera and Arka (Calotropis gigantea) $k s h e e r a$. This paste is then smeared on No 20 Surgical linen thread. The Varthi is prepared in different diameters and kept in an airtight container. The Varthi prepared with these sodhana ropana drugs will do the debridement of slough and unhealthy tissues alleviate the dosha and promote the healing of the track.

\section{Patient Information}

A male patient aged 44 years, came to the OPD Government Ayurveda College, Trivandrum with intermittent pus discharge from the perianal region for 2 years. He didn't seek any treatment for the same. On local examination, an opening is found in the left side of the perianal region 4 o' clocks about $2 \mathrm{~cm}$ away from the anal verge which bursts spontaneously and leads to discharge. The track was intact and covered by the skin. On per rectal examination, no internal openings are felt. As per the MRI, a grade 1 intersphincteric sinus_tract was noted. Due to its recurrence and because of psychological disturbances he is unable to do his routine activities. He is having a history of Hypertension, Dyslipidemia, and seizures.

\section{INVESTIGATIONS}

His routine examinations were found to be within normal. As per the MRI, a short intersphincteric sinus track was noted extending from a cutaneous opening in the left perianal region at a 5-o clock position, directly entering the intersphincteric plane. It courses superiorly for $1.3 \mathrm{~cm}$ and then stops.

\section{PROCEDURE DONE}

Consent was obtained from the patient. Preoperative procedures were done properly. Ghontaphaladi Varthi is prepared as per the reference in Susrutha samhitha Nadi Vrana chikitsa. The size of the tract is assessed using the probe and previously prepared Varthi is inserted into the tract. Daily cleaning was done using sterile water. The Varthi was changed daily and assessment of the healing of the track was done weekly by assessing the length. The details of procedures and observation are presented in the below table:

\section{Duration observation}

25/11/20 Site is made aseptic and Varthi is inserted after probing to make the tract clear. The length was assessed as $2 \mathrm{~cm}$.

$29 / 11 / 20$

The track was found opened. No pus discharges. Healthy granulation tissue is present on the floor of the wound.

2/12/20 The length of the track is 1.9 $\mathrm{cm}$

$10 / 12 / 21$

$17 / 12 / 20$ length reduced to $0.8 \mathrm{~cm}$ wound bed was fully covered with granulation tissue.

21/12/20 complete healing of the wound. 


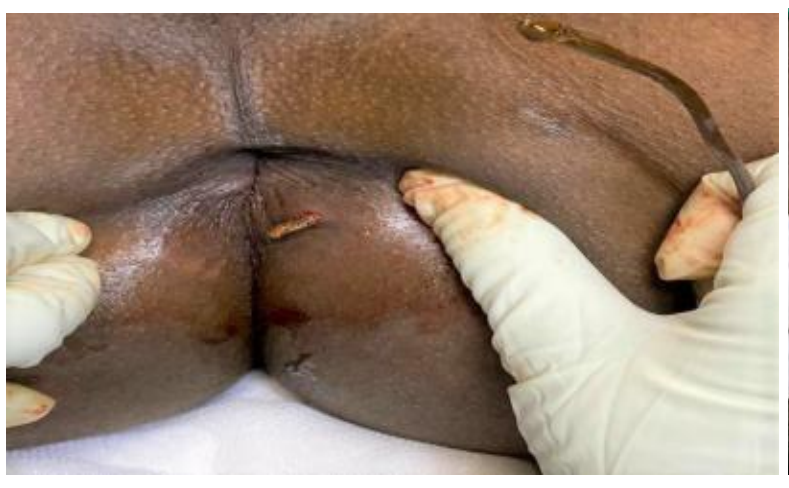

\section{Varthi applied after treatment}

Advice: The patient is advised to take fibre rich food to avoid constipation and diet regulations applicable for wound patient is also mentioned.

\section{Results}

Daily application of Varthi for 4 weeks resulted in complete cutting and healing of the track.

\section{DISCUSSION}

The drugs used in the Varthi are ghontaphala twak, panchalavana, laksha, poogaphala, alavanapatra, snuhiksheera and arkaksheera ${ }^{3}$

The properties of the drugs used are as follows: The ghonta phala is having vrana sodhana and ropana properties as its having kashaya rasa. The kshara nature and tikshna guna of lavana will help in the scraping of the fibrous tissue and it is also having ropana guna. Laksha is possessing vranaropana guna, twak rakta dosha hara, krimighna etc gunas. Puga phala is having kashaya rasa which helps in vrana ropana, ruksha and vikasi guna help in penetrating deeper into the tissues. Tikshna ushna guna of alavana patra and snuhi helps in deeper penetration to tissues and do removal of the fibrous tissues. The arka is also having krimghna and sodhana ropana action.

So, the drugs in ghontaphaladi Varthi are tikshna, sukshma, sara, krimighna and vishaghna gunas. The drugs will penetrate deeper into the tissues and act by destroying the fibrous tissues and promoting healing by helping in the formation of healthy granulation tissue. Most of the drugs are having kashaya rasa and this will promote healing. So, this Varthi will do sodhana and ropana of the tract. Further on comparing with the modern surgeries, there is no need for

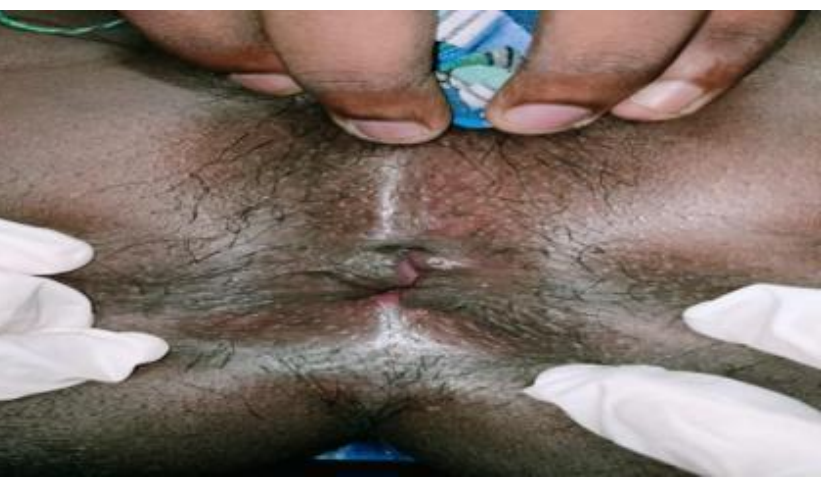

anaesthesia, and no extensive wounds are created. So, this procedure has low cost or expense and has fewer cosmetic issues.

\section{CONCLUSION}

The present study shows that the Ghontaphaldi Varthi is effective in the management of the Nadi Vrana. It has got good wound cleansing and healing property.

\section{REFERENCES}

1. Acharya Sushrutha, Susrutha Samhita with the English translation of text and Dalhana commentary, Dwivraneeya Chikitsa Edited by Prof. K.R. Srikanth Murthy, Chowkhamba Orientalia Varanasi, Reprint edition 2012, Volume 2, Published by Krishnadas Academy.

2. Acharya Sushrutha, Susrutha Samhita with the English translation of text and Dalhana commentary, Visarpa Nadi Sthana roga Chikitsastahan sloka edited by Prof. K.R. Srikantha Murthy, Chowkhamba Orientalia Varanasi, Reprint edition 2016, volume1, Published by Krishnadas Academy.

3. Dr J.L.N. Sastry, DravyagunaVijnana, Volume- II, Chowkhambaorientalia,Varanasi.

\section{Source of Support: Nil Conflict of Interest: None Declared}

How to cite this URL: Sreeparvathy A.G et al: Effect Of Ghontaphaladi Varthi In The Management Of Perianal Sinus A Case Report. International Ayurvedic Medical Journal \{online\} 2021 \{cited October 2021\} Available from: http://www.iamj.in/posts/images/upload/2641_2643.pdf 